\title{
ARTIKEL PENELITIAN \\ GAMBARAN INFEKSI PROTOZOA INTESTINAL PADA ANAK BINAAN RUMAH SINGGAH AMANAH KOTA PADANG
}

\author{
Nurhayati \\ Parasitologi Fakultas Kedokteran Universitas Andalas \\ E-mail: nurhayatikaidir@yahoo.co.id
}

\begin{abstract}
Abstrak
Infeksi protozoa intestinal masih merupakan masalah kesehatan masyarakat di negara tropis dan negara berkembang. Yang termasuk ke dalam protozoa intestinal patogen di antaranya adalah G. lamblia dan E. histolitika.

Telah dilakukan penelitian terhadap anak binaan Rumah Singgah "Amanah", Kelurahan Rimbo Kaluang, Kecamatan Padang Barat, Kota Padang. Pemeriksaan tinja dilakukan terhadap 66 anak dengan metode langsung menggunakan eosin dan lugol. Tujuan penelitian ini adalah untuk mengetahui gambaran infeksi protozoa intestinal pada anak binaan rumah singgah Amanah.

Telah dilakukan penelitian di Rumah Singgah "Amanah", Kelurahan Rimbo Kaluang, Kecamatan Padang Barat, Kota Padang, terhadap anak bia

Hasil penelitian ini menunjukkan bahwa anak-anak yang terinfeksi protozoa intestinal sebesar 40,91\%. Berdasarkan jenis spesies, distribusi frekuensi terbanyak yang menginfeksi anak adalah G. lamblia yaitu $37,88 \%$, sedangkan infeksi oleh $E$. histolitika adalah 3,03\%. Frekuensi infeksi G. Lamblia lebih tinggi pada umur $<10$ tahun yaitu 27,27\%, tetapi pada infeksi E. histolitika terlihat tidak ada perbedaan. Distribusi infeksi berdasarkan jenis kelamin hampir sama pada $G$. lamblia maupun E. histolitika. Berdasarkan pekerjaan, lebih separuh anak binaan yang terinfeksi protozoa intestinal bekerja sebagai penjaja makanan.

Kata kunci: Protozoa intestinal, G. lamblia, E. histolitika
\end{abstract}

\section{Abstract}

Prevalence of intestinal protozoan infection in Rumah Singgah Amanah, Kota Padang. Intestinal protozoan infection is still a public health problem in tropical countries and developing countries. The intestinal protozoan pathogen of which is G. lamblia and E.histolitika.

This research is descriptif study and it was conducted in Rumah Singgah Amanah, Kelurahan Rimbo Kaluang, Kecamatan Padang Barat, Kota Padang. Stool examination has been carried out to 66 children by direct fecal examination method using eosin and Lugol. The purpose of this research is to know the description of intestinal protozoan in fection in Rumah Singgah Amanah.

Prevalence of intestinal protozoa infection was 40,91\%, the highest frequent infection was G. lamblia which was $37.88 \%$, E. histolitika was $3.03 \%$. Frequency 
of G. lamblia infection was higher in age $<10$ years is $27.27 \%$. There was no different in age in E.histolytica infection. There was no different in sex in both infection. Half of children with intestinal protozoa infection were food seller.

Key words : Intestinal Protozoa, G. lamblia, E. histolitika 


\section{Pendahuluan}

Penyakit infeksi parasit usus terutama yang disebabkan oleh protozoa masih menjadi masalah kesehatan di negara-negara berkembang, seperti Indonesia. Walaupun telah dilakukan pemberantasan sejak lama dengan pengobatan dan lain-lain, prevalensi penyakit ini masih cukup tinggi karena rantai penularan oleh sumber infeksi terus terjadi. ${ }^{(1)}$ Orangorang yang berperan dalam penularan adalah mereka yang dalam tinjanya mengandung kista meskipun < $90 \%$ dari mereka sehat. ${ }^{(2)}$

Sejak krisis moneter yang melanda Indonesia di pertengahan tahun 1997 jumlah keluarga yang berada di bawah garis kemisikinan bertambah. Akibatnya, jutaan keluarga terpaksa menurunkan kualitas kehidupan mereka, memaksimalkan aset yang mereka punyai, khususnya tenaga, termasuk tenaga anak-anak agar dapat bertahan hidup. Kondisi ini membawa dampak negatif yang luar biasa bagi anak-anak usia sekolah. Anak-anak harus putus sekolah. Laporan dari salah satu surat kabar di Indonesia, Kompas 14 Agustus 1996, bahwa angka putus sekolah sudah mencapai 1,2 juta per tahun untuk tingkat SD dan 450.000 per tahun untuk SLTP. Dalam banyak kasus, anak-anak putus sekolah terpaksa memasuki dunia kerja dengan tujuan meringankan beban keluarga akibatnya salah satu masalah sosial yang timbul di berbagai kota besar pasca krisis adalah berkembangnya anak jalanan. ${ }^{(3)}$

Untuk bertahan hidup di tengah kehidupan kota yang keras dan membantu orang tua mencari nafkah, anak-anak jalanan biasanya melakukan pekerjaan di sektor informal. Ada yang bekerja sebagai pedagang asongan, menjajakan koran dan makanan, menyemir sepatu, mengamen di perempatan lampu merah, mencari barang bekas atau sampah, dan tidak jarang pula ada anak-anak yang terlihat pada jenis pekerjaan berbau kriminal. ${ }^{(3)}$

Kemiskinan bukan merupakan satu-satunya faktor determinan yang menyebabkan anak-anak lari dari rumah dan terpaksa hidup di jalanan. Menurut penjelasan Justika $S$ Baharsjah, kebanyakan anak bekerja bukanlah atas kemauan mereka sendiri melainkan $60 \%$ diantaranya karena dipaksa oleh orang tuanya. Biasanya anak-anak ini memiliki orang tua yang berpendidikan rendah, wawasan tentang anak dan kesehatan juga rendah. Hal tersebut merupakan salah satu faktor pendorong timbulnya caracara hidup yang tidak sehat. Akibat dari cara hidup yang tidak sehat ini, mereka terbiasa kurang memperhatikan kebersihan pribadi maupun lingkungan yang nantinya dapat menyebabkan penyakit pada anak tersebut dan menjadi sumber infeksi bagi orang lain di sekitarnya. ${ }^{(3)}$

Apabila ditinjau kembali latar belakang pekerjaan anak-anak jalanan, kebiasaan dan cara hidup mereka, memungkinkan anak-anak jalanan akan terus-menerus terpapar oleh agent infeksi. Hal ini disebabkan oleh keseharian mereka di jalanan berkontak dengan lingkungan kotor, memakan makanan dan minuman yang tidak higienis, serta kurangnya pengetahuan akan pentingnya kebersihan perorangan, membuat anak-anak ini termasuk orang yang beresiko terhadap infeksi parasit salah satunya infeksi protozoa intestinal.

Upaya yang telah dilakukan untuk menangani anak-anak jalanan biasanya adalah dengan berusaha mengeluarkan mereka dari jalanan, memasukkannya ke berbagai "rumah singgah", tempat-tempat pelatihan, dan sejenisnya dengan harapan setelah 
diberi bekal pendidikan dan keterampilan tertentu, kemungkinan mereka untuk kembali ke jalanan dapat dieliminasi. $^{(3)}$

Rumah Singgah "Amanah" yang berlokasi di Kelurahan Rimbo Kaluang, Kecamatan Padang Barat adalah salah satu rumah singgah dari empat rumah singgah yang ada di Kota Padang yang aktif berupaya melakukan pembinaan terhadap anak-anak jalanan. Jika dibandingkan dengan ketiga rumah singgah lain, rumah singgah Amanah merupakan rumah singgah yang anak binaannya berlatar belakang sosial ekonomi sangat kurang. Secara geografis terletak di pinggir kali dan berjarak 50 meter dari pantai, sehingga anak-anak yang dibina juga kebanyakan berasal dari perkampungan nelayan. Ada 100 anak jalanan yang dibina di rumah singgah tersebut. Anak-anak tersebut kebanyakan mempunyai keluarga dan bertempat tinggal tidak jauh dari rumah singgah Amanah. ${ }^{(4)}$

Di Padang khususnya data dan informasi mengenai anak-anak jalanan masih sangat kurang, jumlah mereka saja tidak diketahui dengan pasti, termasuk data-data mengenai kondisi kesehatan anak-anak ini. Padahal informasi dan data ini sangat diperlukan untuk lebih memahami kondisi anak-anak tersebut sehingga nantinya dapat memberikan solusi atas permasalahan mereka.

Belum adanya laporan sebelumnya yang menggambarkan bagaimana gambaran infeksi protozoa usus pada rumah-rumah singgah, membuat peneliti tertarik ingin mengangkat topik penelitian ini. Dengan hasil yang diharapkan nantinya dapat membantu upaya pencegahan penyakit infeksi yang disebabkan oleh protozoa intestinal di rumah singgah tersebut.

\section{METODE PENELITIAN}

Desain penelitian ini adalah penelitian deskriptif. Penelitian dilaksanakan pada bulan Agustus 2005 sampai Februari 2006. Tempat penelitian adalah di Rumah Singgah "Amanah", Kelurahan Rimbo Kaluang, Kecamatan Padang Barat. Pemeriksaan tinja dilakukan di Laboratorium Parasitologi Fakultas Kedokteran Universitas Andalas Padang.

Populasi pada penelitian ini adalah seluruh anak binaan Rumah Singgah "Amanah". Sampel adalah semua populasi yang memenuhi kriteria inklusi, yaitu yang mengembalikan pot plastik berisi tinja.

\section{Cara Kerja}

Pertama-tama diberikan penerangan tentang tujuan penelitian kepada kepala yayasan dan anak binaan rumah singgah, kemudian dibagikan pot plastik kepada tiap anak untuk diisi dengan tinja yang akan dikumpulkan pada esok harinya. Pada hari-H, anak yang datang didata nama, umur, jenis kelamin, dan pekerjaannya sambil membawa tinja dalam pot plastik yang telah diberi label nama. Tinja yang telah terkumpul dibawa dan diperiksa di Laboratorium Parasitologi Fakultas Kedokteran Unand.

Pemeriksaan tinja dilakukan dengan pewarnaan langsung, yaitu dengan pewarnaan eosin $2 \%$ dan lugol. Diteteskan setetes larutan eosin 2\% diatas kaca objek yang bersih dan kering pada satu sisi kaca objek dan stetes lugol pada sisi lain. Kemudian ambil tinja dengan ujung lidi yang beriih, lalu dioleskan pada tetesan tadi dan diaduk rata dengan lidi, bagianbagian kasar dibuang, lalu ditutup dengan kaca tutup. Sediaan harus tipis, yang ditandai oleh warnanya yang merah muda. Jika warnanya pink tua 
atau merah tuan berarti sediaan terlalu tebal.

Agar tidak terjadi gelembung udara, kaca tutup diletakkan secara perlahan-lahan. Sesudah itu sediaan dilihat dibawah mikroskop dengan pembesaran objektif 10 x 10 dari kiri ke kanan dan dari atas ke bawah sehingga seluruh lapangan pandang teramati. Bila sudah ditemukan parasit maka dikonfirmasi dengan lensa $10 \mathrm{x}$ 45 .

Data yang diperoleh dikumpulkan lalu dikelompokkan menurut umur, jenis kelamin dan pekerjaan. Data diolah secara manual dan disajikan dalam bentuk tabel distribusi frekuensi.

\section{HASIL PENELITIAN}

Rumah singgah Amanah
berlokasi di Kelurahan Rimbo
Kaluang, Kecamatan Padang Barat,
merupakan salah satu rumah singgah
dari empat rumah singgah di Kota
Padang yang aktif berupaya melakukan
pembinaan terhadap anak-anak jalanan.

Secara geografis terletak di lingkungan perkampungan nelayan, 50 meter dari pantai, dekat pinggir kali. Kira-kira 50 meter di belakang rumah singgah terdapat pasar tradisional tempat sebagian anak rumah singgah tersebut berjualan makanan. Lingkungan sekitarnya terlihat tidak sehat karena tidak mempunyai tempat pembuangan sampah di tiap rumah, sampah terlihat dibiarkan menumpuk di pinggir pantai dan sepanjang kali. Sebagian besar penduduk tidak mempunyai jamban keluarga. Penduduknya sebagian besar bermata pencaharian sebagai nelayan, namun ada juga sebagai pedagang. Ada 100 anak jalanan yang dibina di rumah singgah tersebut. Anak-anak tersebut kebanyakan mempunyai keluarga dan bertempat tinggal tidak jauh dari rumah singgah Amanah.

Telah dilakukan penelitian di Rumah Singgah Amanah dengan sampel berjumlah 66, yang terkumpul dari anggota populasi penelitian. Berdasarkan sampel yang ada, diperoleh hasil sebagai berikut : 
Tabel 1. Karakteristik Anak Binaan Rumah Singgah Amanah Kelurahan Rimbo Kaluang Kecamatan Padang Barat.

\begin{tabular}{clcc}
\hline & Karakteristik & $\begin{array}{c}\text { Jumlah } \\
\text { (orang) }\end{array}$ & \% \\
\hline \multirow{2}{*}{ Umur (tahun) } & $<10$ & 46 & 69,69 \\
& $>10$ & 20 & 30,31 \\
\hline \multirow{2}{*}{ Jenis Kelamin } & Laki-laki & 42 & 63,63 \\
& Perempuan & 24 & 36,36 \\
\hline \multirow{2}{*}{ Pekerjaan } & Penjual makanan & 27 & 40,91 \\
& Bukan penjual makanan & 39 & 59,09 \\
\hline
\end{tabular}

Berdasarkan tabel 1 dapat diketahui bahwa sebagian besar $(69,69 \%)$ anak binaan rumah singgah Amanah berumur $\leq 10$ tahun. Laki-laki hampir dua kali lebih banyak $(63,63 \%)$ daripada anak perempuan $(36,36 \%)$. Menurut jenis pekerjaan, sebanyak 40,91\% anak-anak binaan rumah singgah bekerja sebagai penjaja makanan.

Tabel 2. Distribusi Frekuensi Kejadian infeksi Protozoa Intestinal

\begin{tabular}{lcc}
\hline \multicolumn{1}{c}{ Kejadian Infeksi } & $\begin{array}{c}\text { Jumlah } \\
\text { (orang) }\end{array}$ & \% \\
\hline Terinfeksi protozoa intestinal & 27 & 40,91 \\
Tidak terinfeksi protozoa intestinal & 39 & 59,09 \\
\hline \multicolumn{1}{c}{ Total } & $\mathbf{6 6}$ & $\mathbf{1 0 0}$ \\
\hline
\end{tabular}

Dari tabel 2 terlihat bahwa hampir separuh anak binaan rumah singgah Amanah terinfeksi oleh protozoa intestinal $(40,91 \%)$.

Tabel 3. Distribusi Frekuensi Infeksi Protozoa Intestinal Berdasarkan Spesies

\begin{tabular}{ccc}
\hline Spesies Protozoa Intestinal & Jumlah & \% \\
\hline Giardia lamblia & 25 & 92,59 \\
Entamoeba histolytica & 2 & 7,41 \\
\hline Total & $\mathbf{2 7}$ & $\mathbf{1 0 0}$ \\
\hline $\mathrm{N}=66$ & &
\end{tabular}

Dari tabel 3 terlihat bahwa spesies protozoa intestinal yang menginfeksi anak binaan rumah singgah Amanah adalah G. lamblia dan E. histolitika, tidak ditemukan spesies lain, dimana Giardia lamblia penyebab infeksi terbanyak. 
Tabel 4 . Distribusi Frekuensi Infeksi Protozoa Intestinal Berdasarkan Umur

\begin{tabular}{|c|c|c|c|c|c|c|c|c|}
\hline \multirow[b]{2}{*}{$\begin{array}{c}\text { Umur } \\
\text { (tahun) }\end{array}$} & \multicolumn{2}{|c|}{ E. histolytica } & \multicolumn{2}{|c|}{ G. lamblia } & \multicolumn{2}{|c|}{ Tidak terinfeksi } & \multicolumn{2}{|c|}{ Total } \\
\hline & $\begin{array}{l}\text { Jumlah } \\
\text { (orang) }\end{array}$ & $\%$ & $\begin{array}{l}\text { Jumlah } \\
\text { (orang) }\end{array}$ & $\%$ & $\begin{array}{l}\text { Jumlah } \\
\text { (orang) }\end{array}$ & $\%$ & $\begin{array}{l}\text { Jumlah } \\
\text { (orang) }\end{array}$ & $\%$ \\
\hline$\leq 10$ & 1 & 1,515 & 18 & 27,27 & 27 & 40,91 & 46 & 69,69 \\
\hline$>10$ & 1 & 1,515 & 7 & 10,61 & 12 & 18,18 & 20 & 30,31 \\
\hline Total & 2 & 3,03 & 25 & $\mathbf{3 7 , 8 8}$ & 39 & 59,09 & 66 & 100 \\
\hline
\end{tabular}

Dari tabel 4 diatas, diketahui bahwa yang terinfeksi Giardia lamblia lebih tinggi pada anak dengan umur $\leq 10$ tahun $(27,27 \%)$, dibandingkan dengan anak umur $\geq$ 10 tahun $(10,61 \%)$. Sedangkan anak yang terinfeksi $E$. histolytica pada anak umur $\leq 10$ tahun dengan anak $>10$ tahun tidak berbeda.

Tabel 5. Distribusi Frekuensi Infeksi Protozoa Intestinal Berdasarkan Jenis Kelamin.

\begin{tabular}{|c|c|c|c|c|c|c|c|c|}
\hline \multirow{2}{*}{$\begin{array}{c}\text { Jenis } \\
\text { Kelamin }\end{array}$} & \multicolumn{2}{|c|}{ E. histolytica } & \multicolumn{2}{|c|}{ G. lamblia } & \multicolumn{2}{|c|}{$\begin{array}{c}\text { Tidak } \\
\text { terinfeksi }\end{array}$} & \multicolumn{2}{|c|}{ Total } \\
\hline & $\begin{array}{l}\text { Jumlah } \\
\text { (orang) }\end{array}$ & $\%$ & $\begin{array}{l}\text { Jumlah } \\
\text { (orang) }\end{array}$ & $\%$ & $\begin{array}{l}\text { Jumlah } \\
\text { (orang) }\end{array}$ & $\%$ & $\begin{array}{l}\text { Jumlah } \\
\text { (orang) }\end{array}$ & $\%$ \\
\hline Laki-laki & 1 & 1,515 & 13 & 19,70 & 28 & 42,42 & 42 & 63,63 \\
\hline Perempuan & 1 & 1,515 & 12 & 18,18 & 11 & 16,67 & 24 & 36,36 \\
\hline Total & 2 & $\mathbf{3 , 0 3}$ & 25 & $\mathbf{3 7 , 8 8}$ & 39 & 59,09 & 66 & 100 \\
\hline
\end{tabular}

Infeksi yang disebabkan oleh Giardia lamblia sedikit lebih tinggi pada anak lakilaki yaitu $19,70 \%$, sedangkan infeksi yang disebabkan E. histolytica memiliki frekuensi sama antara anak laki-laki dan perempuan (Tabel 5).

Tabel 6. Distribusi Infeksi Protozoa Intestinal Berdasarkan Stadium Parasit Yang Ditemukan.

\begin{tabular}{ccccc}
\hline \multirow{2}{*}{$\begin{array}{c}\text { Stadium } \\
\text { parasit }\end{array}$} & \multicolumn{2}{c}{ E. histolytica } & \multicolumn{2}{c}{ G. lamblia } \\
\cline { 2 - 5 } & $\begin{array}{c}\text { Jumlah } \\
\text { (orang) }\end{array}$ & $\mathbf{\%}$ & $\begin{array}{c}\text { Jumlah } \\
\text { (orang) }\end{array}$ & $\%$ \\
\hline tropozoit & 0 & 1,515 & 0 & 19,70 \\
kista & 1 & 1,515 & 25 & 18,18 \\
\hline Total & $\mathbf{2}$ & $\mathbf{3 , 0 3}$ & $\mathbf{2 5}$ & $\mathbf{3 7 , 8 8}$ \\
\hline
\end{tabular}

Dari tabel di atas dapat dilihat bahwa semua anak yang terinfeksi hanya mengandung protozoa stadium kista, tidak ada yang mengandung stadium tropozoit, baik infeksi oleh G. lambia ataupun E. histolitika.

\section{PEMBAHASAN}

Pada penelitian ini didapatkan bahwa hampir separuh anak binaan rumah singgah Amanah terinfeksi oleh protozoa intestinal $(40,91 \%)$. Ini berarti anak-anak tersebut telah minum air atau memakan makanan yang terkontaminasi dengan protozoa sebelumnya. Infeksi protozoa bisa saja didapat dari sumber air minum yang tidak bersih, makanan yang tercemar, ${ }^{(5)}$ dan tangan yang kotor. ${ }^{(6)}$ Semua itu dipengaruhi oleh higiene perorangan 
dan sanitasi yang buruk. $^{(2)}$ Dari penelitian yang dilaksanakan oleh Nurhayati sebelumnya ${ }^{(4)}$ ditempat yang sama, didapatkan $60 \%$ anak-anak rumah singgah Amanah memiliki kebiasaan sehari-hari kurang baik, seperti buang air besar di kali atau di pantai, tidak mencuci tangan sebelum makan, dan memiliki kuku yang panjang dan kotor. Hal tersebut menyebabkan tingginya kejadian infeksi protozoa pada anak tersebut.

Berdasarkan spesies penyebab, Giardia lamblia merupakan protozoa yang paling banyak menginfeksi anak binaan rumah singgah amanah (37,88\%), menyusul Entamoeba histolytika $(7,41 \%)$. Bila dibandingkan dengan hasil penelitian sebelumnya, dimana prevalensi infeksi Giardia lamblia pada anak-anak di negaranegara berkembang berkisar antara 15$20 \%,{ }^{(7)}$ maka angka yang didapatkan pada penelitian ini jauh lebih tinggi, sedangkan infeksi E. histolitika tergolong rendah bila dibandingkan dengan penelitian terdahulu Aziz ${ }^{(8)}$ yang mendapatkan angka 5-10 \% di kota Padang. Hal tersebut mungkin berkaitan dengan usia subjek penelitian. Dari penelitian Andreas $\mathrm{A},{ }^{(9)}$ prevalensi E. histolitika tertinggi pada anak umur $<2$ tahun dan dewasa umur 20-50 tahun, sedangkan anakanak di Rumah Singgah Amanah berumur 7 tahun sampai 19 tahun.

Bila dilihat berdasarkan umur, maka infeksi Giardia lamblia lebih tinggi pada anak dengan umur $\leq 10$ tahun $(27,27 \%)$, dibandingkan dengan anak umur $\geq 10$ tahun $(10,61 \%)$, tetapi pada penelitian ini tidak dilakukan uji statistik. Sedangkan infeksi $E$. histolytika tidak berbeda pada kelompok umur.

Infeksi yang disebabkan oleh Giardia lamblia tampak lebih tinggi pada anak laki-laki dibanding perempuan, hanya saja pada penelitian ini tidak disertai dengan uji statistik, sedangkan infeksi yang disebabkan $E$. histolytica memiliki frekuensi sama antara anak laki-laki dan perempuan. Rentan atau tidaknya seorang anak terhadap infeksi protozoa intestinal dipengaruhi oleh status gizi, umur, hygiene perorangan, sanitasi lingkungan sekitar, keadaan sosial ekonomi, serta adanya komplikasi dengan infeksi parasit atau bakteri lain. $^{(2)}$ Dalam hal ini tidak ada hubungannya dengan jenis kelamin.

Anak yang terinfeksi oleh protozoa pada penelitian ini, semuanya mengandung kista, tidak satupun anak ditemukan mengandung stadium tropozoit, ini berarti bahwa semua anak sedang berada dalam status carrier. Meski tidak memperlihatkan gejala, dengan ditemukannya protozoa stadium kista, mereka telah memegang peranan penting sebagai sumber penularan penyakit protozoa, apalagi hampir separuh dari mereka bekerja sebagai penjaja makanan. Karena kista merupakan bentuk infektif dari protozoa baik $E$. histolitika maupun $G$. lamblia. ${ }^{(2)}$ Higiene pribadi yang tidak baik, dimana tangan yang kotor dan kuku yang panjang dengan mudah memindahkan kista yang lengket ditangan kepada orang lain melalui makanan yang mereka jual, lebih lagi bila makanan tersebut tidak berbungkus.

Pencegahan infeksi oleh protozoa dapat dilakukan dengan meningkatkan hygiene perorangan dan menjaga agar makanan dan minuman tetap bersih, tidak tercemar dengan kista E. histolytica maupun G. lamblia yang dibawa oleh lalat, lipas atau tikus, menjaga kebersihan alat-alat makan dan memasak makanan dan minuman dengan sempurna. ${ }^{(10)}$ Untuk memutus rantai penularan, maka para carrier 
amubiasis dan giardiasis (pengandung kista) harus diobati. ${ }^{(2)}$

\section{KESIMPULAN}

Dari hasil penelitian dapat disimpulkan sebagai berikut:

1. Anak binaan Rumah Singgah Amanah lebih banyak pada kelompok umur rentan yaitu $\leq$ 10 tahun, anak laki-laki dua kali lebih banyak dari anak perempuan, dan hampir separuh anak bekerja sebagai penjaja makanan.

2. Hampir separuh anak binaan rumah singgah Amanah terinfeksi oleh Protozoa Intestinal $(40,91 \%)$.

3. Berdasarkan jenis spesies, frekuensi infeksi tertinggi disebabkan oleh Giardia lamblia.

4. Distribusi infeksi berdasarkan umur, Giardia lamblia banyak pada anak berumur kurang dari 10 tahun dari pada umur lebih 10 tahun, sedangkan $E$. histolytika tidak dapat dibandingkan karena angka kejadian yang sedikit.

5. Distribusi infeksi protozoa intestinal pada anak laki-laki hampir sama dengan anak permepuan.

6. Lebih dari separuh anak yang terinfeksi protozoa intestinal bekerja sebagai penjaja makanan.

\section{SARAN}

1. Perlunya diberikan penyuluhan yang intensif dan berkelanjutan kepada anak-anak binaan rumah singgah dan masyarakat sekitarnya tentang pentingnya kebersihan dan kesehatan diri dan lingkungan serta kerugian yang ditimbulkan oleh infeksi protozoa intestinal.

2. Pengobatan terhadap anak binaan rumah singgah Amanah yang telah terinfeksi oleh protozoa Intestinal (carrier).

\section{KEPUSTAKAAN}

1. Enggarfitri L, Baskoro A, Santoso N. Protozoa usus patogen yang ditemukan pada anak diare degan berbagai status gizi. Majalah Kedokteran UniBraw 1996;12:14-19.

2. Wolfe, MS. Giardiasis. Clinical Microbiology Reviews 1992; 5(1): 93-100.

3. Sularto. Potret Kehidupan Anak Indonesia. World Vision Indonesia 2000.world vision Indonesia 9-90.

4. Nurhayati. Upaya menurunkan kejadian infeksi soil Transmitted Helminth pada anak binaan Rumah Singgah Amanah Padang 2005. Laporan Pengabdian Masyarakat IPTEKS Dana Dikti 2005.

5. Dawson D. Foodborn protozoan parasites. International Journal of Food Microbiology 2005; 103: 207- 227.

6. Rinnea S, Edgar JR, Regina G, Nita G, Larry TG. Prevalence and risk factors for protozoan and nematode infections among children in an Ecuadorian highland community. Transactions of the Royal Society of Tropical Medicine and Hygiene 2005; 99: 585592. 
7. Stephanie S, Hale D. Giardia. Lange A Medical Book: Current Diagnosis and Treatment in infectious diseases 2001. Mc Graw-Hill, USA: 836-840.

8. Aziz A. Masalah Amubiasis dan Penanganannya di Lapangan. Fakultas kedokteran Universitas Andalas 1992, Padang.
9. Andreas A, AlRasjid H. Abses amuba pada hepar. Majalah Medika 2002; (9): 607-611.

10. Sudarto. Protozoology Kedokteran. Majalah Widya Medika 1995: 61-64 